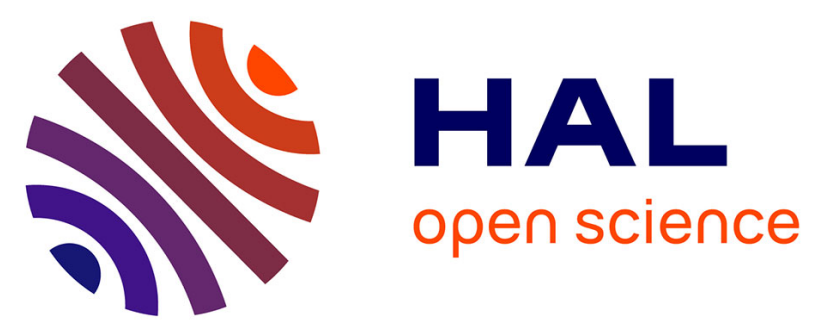

\title{
The gene expression profile of psoralen plus UVA-induced premature senescence in skin fibroblasts resembles a combined DNA-damage and stress-induced cellular senescence response phenotype
}

Céline Borlon, Florence Debacq-Chainiaux, Christina Hinrichs, Karin

Scharffetter-Kochanek, Olivier Toussaint, Meinhard Wlaschek

\section{To cite this version:}

Céline Borlon, Florence Debacq-Chainiaux, Christina Hinrichs, Karin Scharffetter-Kochanek, Olivier Toussaint, et al.. The gene expression profile of psoralen plus UVA-induced premature senescence in skin fibroblasts resembles a combined DNA-damage and stress-induced cellular senescence response phenotype. Experimental Gerontology, 2007, 42 (9), pp.911. 10.1016/j.exger.2007.04.009 . hal00499013

\section{HAL Id: hal-00499013 \\ https://hal.science/hal-00499013}

Submitted on 9 Jul 2010

HAL is a multi-disciplinary open access archive for the deposit and dissemination of scientific research documents, whether they are published or not. The documents may come from teaching and research institutions in France or abroad, or from public or private research centers.
L'archive ouverte pluridisciplinaire $\mathbf{H A L}$, est destinée au dépôt et à la diffusion de documents scientifiques de niveau recherche, publiés ou non, émanant des établissements d'enseignement et de recherche français ou étrangers, des laboratoires publics ou privés. 


\section{Accepted Manuscript}

The gene expression profile of psoralen plus UVA-induced premature senescence in skin fibroblasts resembles a combined DNA-damage and stress-induced cellular senescence response phenotype

Céline Borlon, Florence Debacq-Chainiaux, Christina Hinrichs, Karin Scharffetter-Kochanek, Olivier Toussaint, Meinhard Wlaschek

PII: S0531-5565(07)00089-7

DOI: 10.1016/j.exger.2007.04.009

Reference: $\quad$ EXG 8336

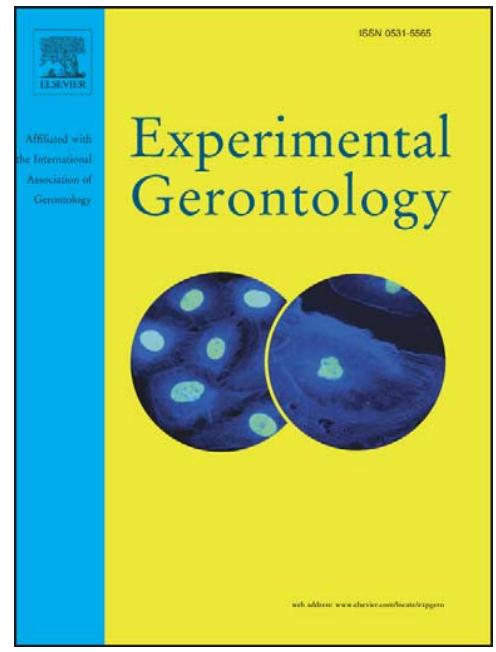

To appear in: $\quad$ Experimental Gerontology

Received Date: $\quad 22$ December 2006

Revised Date: $\quad 19$ April 2007

Accepted Date: $\quad 24$ April 2007

Please cite this article as: Borlon, C., Debacq-Chainiaux, F., Hinrichs, C., Scharffetter-Kochanek, K., Toussaint, O., Wlaschek, M., The gene expression profile of psoralen plus UVA-induced premature senescence in skin fibroblasts resembles a combined DNA-damage and stress-induced cellular senescence response phenotype, Experimental Gerontology (2007), doi: 10.1016/j.exger.2007.04.009

This is a PDF file of an unedited manuscript that has been accepted for publication. As a service to our customers we are providing this early version of the manuscript. The manuscript will undergo copyediting, typesetting, and review of the resulting proof before it is published in its final form. Please note that during the production process errors may be discovered which could affect the content, and all legal disclaimers that apply to the journal pertain. 


\section{Title}

2 The gene expression profile of psoralen plus UVA-induced premature senescence in skin 3 fibroblasts resembles a combined DNA-damage and stress-induced cellular senescence response 4 phenotype

\section{Authors}

9 Céline Borlon ${ }^{1}$, Florence Debacq-Chainiaux ${ }^{1}$, Christina Hinrichs ${ }^{2}$, Karin Scharffetter-Kochanek ${ }^{2}$, 10 Olivier Toussaint ${ }^{1}$, Meinhard Wlaschek ${ }^{2}$

$11{ }^{1}$ Research Unit on Cellular Biology (URBC), Department of Biology, University of Namur 12 (FUNDP), Rue de Bruxelles, 61, B-5000 Namur, Belgium

13 '2 Department of Dermatology and Allergic Diseases, University of Ulm, Maienweg 12, 89081 14 Ulm, Germany

\section{Corresponding author:}

18 Meinhard Wlaschek

Department of Dermatology and Allergic Diseases

University of Ulm

Maienweg 12

89081 Ulm, Germany

Phone : 004973150057593

Fax : 004973150046111

Email : Meinhard.Wlaschek@uni-ulm.de

\section{Running title :}

Gene profiling of PUVA-induced premature senescence

\section{Key words}

psoralen, ultraviolet A irradiation, cellular senescence, fibroblasts, gene expression, stress- 


\section{Abstract}

2 After a finite number of population doublings, normal human cells undergo replicative 3 senescence accompanied by growth arrest. We previously described a model of stress-induced 4 premature senescence by treatment of dermal fibroblasts with psoralen plus UVA, a common 5 photodermatological therapy. Psoralen photoactivation has long been used as a therapy for 6 hyperproliferative skin disorders. The repetitive therapeutical treatment is accompanied by 7 premature aging of the skin. Treatment of fibroblasts in vitro with 8-methoxypsoralen (8-MOP) 8 and subsequent ultraviolet A (UVA) irradiation results in growth arrest with morphological and 9 functional changes reminiscent of replicative senescence. For gene expression profiling in two strains of human skin fibroblasts after PUVA treatment, we used a low density DNA array representing 240 genes involved in senescence and stress response. Twenty-nine genes were differentially expressed after PUVA treatment in the two strains of human skin fibroblasts. These genes are involved in growth arrest, stress response, modification of the extracellular matrix and senescence. This study contributes further to the elucidation of the PUVA model and its validation as a useful stress-induced premature senescence model aiming to characterize the premature senescence of fibroblasts and to identify biomarkers that could be applied in vivo. 


\section{Introduction}

There is now increasing evidence that cellular senescence in vitro reflects - at least in part cellular aging in vivo (Patil et al., 2005). Recently, the development of different premature senescence inducing models has extended our knowledge of basic molecular mechanisms. Extrinsic as well as intrinsic cellular senescence mechanisms overlap in vivo. The underlying molecular mechanisms can be analyzed in detail by inducing premature senescence in dermal fibroblasts in vitro. In dermatological phototherapy, the therapeutic properties of psoralens have been used for long time. The antiproliferative effects of photosensitized psoralens are related to the ability of their tricyclic aromatic structure to absorb ultraviolet radiation and to generate DNA-damage. PUVA-therapy with 8-methoxypsoralen and long-wave ultraviolet-A (320-400 $\mathrm{nm}$ ) irradiation has been used in the treatment of inflammatory and neoplastic skin disorders like psoriasis and T-cell lymphoma. Interestingly, premature aging of the skin has been observed in these patients (Sator et al., 2002). Application of PUVA treatment to dermal fibroblasts induced a long term switch of mitotically active fibroblasts to post-mitotic fibroblasts mimicking several features of replicative senescence (Herrmann et al., 1998; Ma et al., 2003; Wlaschek et al., 2003), including the activation of the senescence associated $\beta$-galactosidase (SA- $\beta$-gal), a biomarker of fibroblast senescence in vivo and in vitro (Dimri et al., 1995). Reactive oxygen species are causally involved in the PUVA-induced permanent growth arrest since superoxide anion radicals and hydrogen peroxide were identified as causal intermediates in the downstream signaling pathway leading to the response of fibroblasts to PUVA treatment (Herrmann et al., 1998). A permanent increase in the synthesis of the matrix-metalloproteases MMP1 and MMP3 (Herrmann et al., 1998) has been observed. Using subtractive hybridization, the genes for the cyclindependent kinase inhibitor $\mathrm{p} 21^{\text {waf-1 }}$, ferritin- $\mathrm{H}$ and tissue inhibitor of metalloproteinase-3 (TIMP3) have been shown to be up-regulated and the genes for apolipoprotein D, laminin B1 and pleiotrophin have been shown to be down-regulated (Wlaschek et al., 2000a; Wlaschek et al., 2000b).

In order to compare in more detail the functional phenotype of cellular senescence with the phenotype obtained following PUVA treatment and other stress-induced premature senescence models, we performed a gene expression and time kinetic study with different fibroblast strains using a low density DNA array representing 240 genes involved in cellular senescence and stress response of human diploid fibroblasts. A selected data set was verified using quantitative RTPCR. We report that the gene expression profile found in fibroblasts submitted to PUVA treatment is comparable to other types of stress induced premature senescence of fibroblasts. We detected genes involved in growth arrest, stress response, modification of extracellular matrix and signal transduction. The reliability of this technology has been fully demonstrated previously (de Longueville et al., 2002; de Magalhaes et al., 2004; Debacq-Chainiaux et al., 2005; Pascal et al., 2005). This technology was already used successfully in different models of stress-induced premature senescence like $\mathrm{H}_{2} \mathrm{O}_{2}$-induced premature senescence of skin HDFs with and without ectopic expression of telomerase (de Magalhaes et al., 2004; Zdanov et al., 2006) and UVBinduced premature senescence of skin HDFs (Debacq-Chainiaux et al., 2005). 


\section{Materials and methods}

\subsection{Cell Culture and PUVA treatment}

AG04431 fetal skin HDFs (Corriel Institute For Medical Research, USA) were grown in DMEM (Dulbecco's Modified Eagle's Medium) (GIBCO-BRL, Eggenstein, Germany) supplemented with 10\% FCS (Fetal Calf Serum) (Biochrom, Berlin, Germany), 2mM L-glutamine, $100 \mu \mathrm{g} / \mathrm{ml}$ streptomycin (Biochrom, Berlin, Germany). Cells were used at $50-60 \%$ of in vitro life span. FF95 fibroblast cultures were established by outgrowth from foreskin of a healthy donor of the age of one year according to the method described earlier (Fleischmajer et al., 1981). The cells were maintained in DMEM supplemented with $10 \%$ FCS, $2 \mathrm{mM} \mathrm{L-glutamine,} 50 \mu \mathrm{g} / \mathrm{ml}$ streptomycin and penicillin $(400 \mathrm{U} / \mathrm{ml})$. Cells were used at cumulative population doublings (CPD) between 10 and 20. Fibroblasts were detached at various days following treatment and cell numbers were determined as described (Bayreuther et al., 1988). Cells were cultured in a humidified atmosphere with $5 \% \mathrm{CO}_{2}$ and $95 \%$ air at $37^{\circ} \mathrm{C}$. Following PUVA-induced growth arrest cells were fed weekly by changing half of the medium.

Cristalline 8-methoxypsoralen (8-MOP) (Sigma, Deisenhofen FRG) was dissolved at $1 \mathrm{mg} / \mathrm{ml}$ in DMSO and stored in the dark. A final concentration of $50 \mathrm{ng} / \mathrm{ml}$ was prepared freshly in DMEM or phosphate buffered saline $\mathrm{pH} 7.4(10 \mathrm{mM}$ phosphate, $0,9 \% \mathrm{NaCl})(\mathrm{PBS})$ directly prior to use. For PUVA treatment, fibroblasts were seeded at a cell density of $3.5^{*} 10^{3} / \mathrm{cm}^{2}$ and incubated for $24 \mathrm{~h}$. Subsequently, cells were pre-incubated for $16 \mathrm{~h}$ with $50 \mathrm{ng} / \mathrm{ml}$ of 8-MOP in DMEM. UVAirradiation was performed on cells incubated with PBS +/- 8-MOP. The cells were irradiated with $90 \mathrm{~kJ} / \mathrm{m}^{2}$ using a high intensity UVA source (UVASUN 3000 equipped with the UVASUN safety filters) emitting wavelengths in the $340-450 \mathrm{~nm}$ range (Mutzhas et al., 1981) as published (Herrmann et al., 1998). Fluences were determined with a UVA-ultraviolet meter (Dr. Hönle, Martinsried). The emission spectrum of the UV source was checked on a regular basis with an Optronics OL-754 radiospectrometer (Optronics, Orlando, FL).

\subsection{Cytotoxicity assay}

The viability of the fibroblasts after PUVA treatment was measured 24 hours after UV-irradiation using 3-(4,5-Dimethylthiazol-2-yl)-2,5-diphenyltetrazolium bromide (MTT, Sigma) by quantifying living metabolically active cells. Mitochondrial dehydrogenases metabolize MTT to purple formazan dye (Green et al 1984). Cytotoxicity was calculated as percentage of formazan formation in cells treated with the PUVA regimen compared to mock-treated cells.

We performed the viability assay for both cell strains. Similar to other fibroblast strains (Herrmann et al 1998), at $24 \mathrm{~h}$ after UV-irradiation of the fibroblasts treated with the 8-MOP, the viability was at least $80 \%$ compared to mock treated fibroblasts of the same strain.

\subsection{Low density DNA-Array}

\section{Microarray design and hybridization}

The DualChip ${ }^{\mathrm{TM}}$ human aging is a low-density DNA array developed in collaboration with Eppendorf (Germany). This array, representing a range of 240 genes involved in senescence and stress response of HDFs, contains two arrays per glass slide (a control and a test) with three subarrays per array. The sequences of the DNA covalently linked to the glass slide were carefully chosen by sequence comparison. Checks were made to ensure that no cross-hybridization takes place. To evaluate the reliability of the experimental data, several positive and negative hybridization and detection controls are included on the microarray. For normalization, internal standard controls and housekeeping genes were arrayed on the slides.

Total RNA was extracted from fibroblasts at $24 \mathrm{~h}, 72 \mathrm{~h}, 1$ week and 4 weeks after PUVA treatment using TRIfast (Peqlab, Germany). Quality control of total RNA was controlled on agarose gels. The amount of RNA was determined spectrophotometrically at $260 \mathrm{~nm}$. Total RNA $(15 \mu \mathrm{g})$ was reverse transcribed using SuperScript II Reverse Transcriptase (Invitrogen, UK). Three independent experiments were performed. Hybridization on DualChip human aging was 
1 carried out as described by the manufacturer. Detection was performed using a Cy3-conjugated

2 IgG anti-biotin (Jackson Immuno Research Laboratories, USA).

3 Imaging, data normalization and statistical analysis

4 Fluorescence of the hybridized arrays was scanned (Packard ScanArray, PerkinElmer, USA) at a resolution of $10 \mu \mathrm{m}$. To maximize the dynamic range of detection, the same arrays were scanned at three photomultiplier gains $(50,70,100)$. The scanned 16-bit images were imported into the ImaGene 4.1 software (BioDiscovery, USA). The fluorescence intensity of each DNA spot (average intensity of each pixel present within the spot) was calculated using local mean background subtraction. A signal was accepted when the average intensity after background subtraction was at least 2.5-fold higher than its local background. The three intensity values of the triplicate DNA spots were averaged and used to calculate the intensity ratio between the reference and the test samples.

The data were normalized in two steps. First, the values were corrected using a factor calculated from the intensity ratios of the 6 internal standards in the reference and test samples. These internal standards were located at two different locations on the array allowing to consider the local background and array homogeneity in the normalization process. The internal standard control does not take into account the purity and quality of the mRNA. Thus, a second step of normalization was performed based on calculating the average intensity for a set of eight housekeeping genes. This set of multiple housekeeping genes, with different expression levels, was preferred to a single reference gene to avoid any bias due to possible variability of the expression level of a single housekeeping gene. Among these housekeeping genes, only genes for which the expression was not changed after a particular treatment were taken into account for the normalization. The variance of the normalized set of housekeeping genes (except those affected by the treatment) was used to generate an estimate of expected variance, leading to a predicted confidence interval to test the significance of the ratios obtained. Ratios outside the $95 \%$ confidence interval were determined to be significantly different (de Longueville et al., 2002; de Magalhaes et al., 2004; Debacq-Chainiaux et al., 2005; Pascal et al., 2005; Zdanov et al., 2006).

\subsection{Validation of relative gene expression by Real Time RT-PCR}

Total RNA $(2 \mu \mathrm{g})$ was reverse transcribed using SuperScript II Reverse Transcriptase (Invitrogen, UK). Primers (Table 1) were designed using the Primer express 1.5 software (Applied Biosystems, The Netherlands). These specific primers correspond to the gene sequence present on the DualChip ${ }^{\mathrm{TM}}$ human aging (Eppendorf, Hamburg, Germany). Amplification reaction assays contained 1X SYBER Green PCR Mastermix (Applied Biosystems, The Netherlands), and primers at optimal concentration. PCR reactions without cDNA were performed as template-free negative controls. All PCR reactions were made in duplicates with a hot start at $95{ }^{\circ} \mathrm{C}$ for 5 minutes, followed by 40 cycles at $95{ }^{\circ} \mathrm{C}$ for 15 seconds and $65^{\circ} \mathrm{C}$ for 1 minute using the 7000 SDS thermal cycler (Applied Biosystems, The Netherlands). Melting curves were generated after amplification. 


\section{Results}

PUVA treatment results in premature aging of the skin in vivo with morphological and functional changes mimicking replicative senescence of fibroblasts in vitro. Distinct features of cellular senescence are observed following PUVA treatment of fibroblasts in vitro. These features include long-term growth arrest, senescent morphology with increased cytoplasm surface, activity of senescence associated- $\beta$ galactosidase, and the increased expression of interstitial collagenase (MMP-1) (Herrmann et al., 1998). In order to find new markers for this stress-induced senescence and to compare the expression profile with other stress-induced premature senescence models to identify common pathways, we used a senescence specific low-density DNA array to estimate the relative mRNA levels of 240 genes involved in senescence and stress response in the two skin fibroblasts strains AG04431 and FF95, submitted to PUVA treatment at the same CPD, as detailed in Materials and Methods. Mock-treated control cells were submitted to all changes of media without 8-MOP pre-incubation and UVA irradiation. The list of the 240 genes represented on this array is available (Debacq-Chainiaux et al., 2005). Total RNA was extracted at $24 \mathrm{~h}, 72 \mathrm{~h}$, 1 week and 4 weeks after PUVA treatment. $15 \mu \mathrm{g}$ RNA were retrotranscribed as described in the Materials and Methods. All cDNA samples were hybridised in triplicates.

We obtained reproducible hybridization patterns on the DualChip ${ }^{\mathrm{TM}}$ human aging for both strains of fibroblasts. Scanning, data mining, normalization and statistical treatment followed previously established procedures. Around 100 genes were found in the triplicates to be differentially expressed in PUVA-induced premature senescence. This large number of variation is not very surprising since all the genes represented on the array are senescence and stress-related. The expression changes of some genes were cell type specific while for others they occurred in a time dependent manner.

Fifty genes showed increased and 44 genes showed decreased transcript levels in FF95 fibroblasts after PUVA treatment. Fourty-nine and 14 genes revealed increased and decreased transcript levels in AG04431 fibroblasts, respectively, after PUVA treatment (Figure 1). These genes are listed in table 2 for FF95 and table 3 for AG04431. A consistent proportion of genes were similarly differentially expressed in both strains of fibroblasts with 23 genes with increased transcript level and 6 genes with decreased transcript level (Table 4).

Most of these genes could be grouped according to their potential involvement in the PUVAinduced phenotype. Here, we present a more detailed analysis for all these commonly differentially expressed genes that can have a potential involvement in the SIPS phenotype reflecting - at least in part - cellular senescence.

\section{Growth and cell-cycle regulated genes}

The cyclin-dependent kinase inhibitor $p 21^{\text {WAF-1 }}$, involved in cell cycle control by regulating cell cycle arrest at the G1/S transition (Sherr and Roberts, 1999), was increased as previously described in replicative senescence. The data on $p 21^{\text {WAF-I }}$ expression confirm the earlier observation that $p 21^{\text {WAF-1 }}$ is induced at the RNA and protein level following PUVA treatment of fibroblasts (Ma et al., 2003; Wlaschek et al., 2000a). The proliferating cell nuclear antigen (PCNA) is a gene involved in DNA repair and DNA replication (Xu and Morris, 1999).

Cyclin D1 (CCND1) was up-regulated in a similar fashion to replicative senescence (Fukami et al., 1995). The up-regulated Cyclin $G 1(C C N G)$ is a damage inducible gene (Bates et al., 1996), and plays a role in modulating apoptosis induced by different stimuli (Okamoto and Prives, 1999). The Connective Tissue Growth Factor (CTGF) was already shown to be down-regulated after UV irradiation. The mechanisms of this down regulation are not yet known (Rittie and Fisher, 2002).

Metallothionein 2A (MT2A) is downregulated and may be involved in the regulation of cell proliferation and apoptosis. Overexpression of $M T 2 A$ can promote tumorigenesis (Simpkins, 2000) (Jin et al., 2001). 
Genes related to stress response

Different genes involved in stress response were upregulated. These include the DNA damage inducible transcript 3 (GADD153) (Park et al., 1992), the heat shock 90kD protein 1 alpha (HSP90- $\alpha$ ) (Humphreys et al., 1999) and heme oxygenase (HMOX). HMOX has been shown to be up-regulated in stress response (Poss and Tonegawa, 1997). Additionally, different antioxidant enzymes were upregulated including the anti oxidant protein 2 (AOP2), also called peroxiredoxin VI (PRXVI), manganese superoxide dismutase (SOD2), glutathione peroxidase (GPX) (Fisher et al., 1999) and glutathione S-transferase theta 1 (GSTT1). GSTT1 was shown to influence tumorigenesis through the transport of oxidized products generated by UV (Strange et al., 1998).

Annexin 1 (ANX1) is a calcium-regulated membrane-binding protein, able to block cell migration. ANX1 shows a co-localization with the stress fibres (Babiychuk et al., 2002). The up-regulation of $A N X 1$ could be linked to the increase of the number of stress fibres previously described in premature senescence in, for instance, $\mathrm{H}_{2} \mathrm{O}_{2}$-induced premature senescence of human fibroblasts (Chen et al., 2000).

\section{Possible effectors in senescence-related genes}

Transforming Growth Factor Beta 1 (TGF $\beta-1$ ) has been previously shown to be over-expressed after exposure of skin fibroblasts to UVB (Chainiaux et al., 2002; Debacq-Chainiaux et al., 2005) and plays a causal role in the molecular mechanism underlying stress-induced premature senescence.

Cathepsin $H(C T S H)$ is associated with protein metabolism and linked to tumor progression (Budihna et al., 1996; Waghray et al., 2002). We also detected $\beta 1$-galactosidase (GLB1), one of the senescence biomarkers (Dimri et al., 1995), which has been described as over-expressed after PUVA treatment (Herrmann et al., 1998).

Some factors involved in oncogenesis are over-expressed such as $R$-ras, a member of the Ras superfamily of small GTP-binding proteins, with a potential transforming activity and a possible role in apoptotic growth control (Cox et al., 1994). SHC transforming protein 1 (SHC) was described as a part of a signal transduction pathway that regulates stress apoptotic responses and life span in mammals (Migliaccio et al., 1999).

\section{Extracellular matrix-associated genes}

We found over-expression of metalloproteinase 14 (MMP14), and down-regulation of metalloproteinase 1 (MMP1), collagen I-alpha (COL1A1), and collagen III-alpha (COL3A1) (Rittie and Fisher, 2002).

Some genes could not be grouped into one of these categories. Urokinase receptor (PLAUR), involved in signal transduction was up-regulated (Borglum et al., 1992). Keratin 19 (KRT19) was already shown to be over-expressed after stress, with its expression depending on the UV wavelength in keratinocytes (Bernerd et al., 2001). Ornithin decarboxylase 1 (ODC) is upregulated after PUVA treatment. It was shown that UVB light induces overexpression of $O D C$, an enzyme that plays a critical role in photocarcinogenesis (Jansen et al., 2001; Lee et al., 2003). $O D C$ activity can be considered as a marker of the mutagenic and carcinogenic effects of UV light (Manzow et al., 2000). BCLX takes part in apoptosis regulation and plays an anti-apoptotic role (Konopleva et al., 1999). It is up-regulated after PUVA treatment. Histone $2 b$ member B/S consensus $(H B 2 / S)$ is upregulated and histone 4 member $M$ consensus $(H 4 F M)$ is downregulated after PUVA. Because histones are the basic nuclear proteins responsible for the nucleosomal structure of the chromosomal fibers in eukaryotes, they contribute to virtually all chromosomal processes, such as gene regulation, chromosome condensation, recombination, and replication.

To verify the expression data generated with the DualChip Human Aging we used quantitative real time RT-PCR of the selected genes $p 21^{\text {WAF-I }}, H M O X, C T G F, M T 2 A$ and SOD2 (Table 5) known to play an important role in cellular senescence and stress response. A cut off of 1.3 was 
1 fixed to select for high relevance. Differential expression observed with real time RT-PCR was 2 higher than with the DNA microarray, because of the sensitivity of the technique. Nevertheless, 3 comparable expression values with the DNA arrays and Real-Time RT-PCR were obtained. 


\section{Discussion}

It was previously shown that a single exposure of human dermal fibroblasts to combined 8methoxypsoralen and UVA irradiation resulted in a cell response related to replicative senescence featuring growth arrest, expression of SA $\beta$-galactosidase (Herrmann et al., 1998), and upregulation of MMP-1 and MMP3 (Herrmann et al., 1998), p21 waf-1, TIMP-3 and ferritin H (Wlaschek et al., 2000a). To better characterize the cellular phenotype, we performed a gene expression study with two different skin fibroblast strains using a low-density DNA array representing 240 genes involved in senescence and stress response and remind only common variations to select more relevant results. Results were confirmed by Real Time RT-PCR.

All gene expression changes observed in this study can link the PUVA-induced changes to a state close to Stress-Induced Premature Senescence. In fact, the differential expression levels observed are similar to the ones observed in a study performed on human fibroblasts in which stress induced premature senescence was induced by UVB (Debacq-Chainiaux et al., 2005).

Growth arrest is an important feature of cellular senescence and stress induced premature senescence. Normal somatic cells enter a state of irreversibly arrested growth after a finite number of divisions (Campisi et al., 1996a; Cristofalo and Pignolo, 1993; Hayflick, 1965). It was already shown that fibroblasts submitted to psoralen photoactivation instantly switch from mitotically active to postmitotically cells even at low CPD (Herrmann et al., 1998). We can correlate this decrease of proliferative potential with the over-expression of $\mathrm{p} 21^{\mathrm{WAF}-1}$ and CCND1 in both strains of fibroblasts, and with the over-expression of $\mathrm{p} 16^{\mathrm{INK} 4 \mathrm{~A}}$ in the AG04431 fibroblasts. In fact, recently we were able to identify $\mathrm{p} 16^{\mathrm{INK} 4 \mathrm{~A}}$ as a robust biomarker for aging in vivo (Ressler et al., 2006). Similar results were found in SIPS induced by UVB in dermal fibroblasts (DebacqChainiaux et al., 2005).

The increased number of SA $\beta$-galactosidase positive cells is a biomarker for senescence in vitro and in vivo (Dimri et al., 1995) as well as for cells entered into SIPS (Dumont et al., 2000). Fibroblasts submitted to PUVA treatment are positive for SA $\beta$-galactosidase (Herrmann et al., 1998; Lee et al., 2006). Here, we confirm the overexpression at the mRNA level of $\beta$ galactosidase in both strains of fibroblasts after PUVA treatment.

It is known that oxidative DNA damage, due to reactive oxygen species, contributes to growth arrest in human diploid fibroblast cells (Chen et al., 1995). In PUVA-induced premature senescence we have shown that ROS are involved in the phenotype of premature senescence (Herrmann et al., 1998). In this study we found several antioxidant enzymes up-regulated such as AOP2, GPX, SOD2 and HMOX. AOP2 was detected to be up-regulated in other studies of stress induced premature senescence following UVB irradiation (Debacq-Chainiaux et al., 2005), or by tert-butylhydroperoxide (Dierick et al., 2002a; Dierick et al., 2002b). Its overexpression was shown to protect cells again phospholipid peroxidation-mediated membrane damage (Manevich et al., 2002), and cytotoxic stress (Dierick et al., 2003; Salmon et al., 2004). GPX and HMOX were already described to show overexpression in fibroblasts entered in SIPS following UVB irradiation (Debacq-Chainiaux et al., 2005).

Recently, it was shown that TGF- $\beta 1$ plays a causal role in the senescence phenotype after UVB stress (Debacq-Chainiaux et al., 2005), as well as $\mathrm{H}_{2} \mathrm{O}_{2}$ stress (Frippiat et al., 2001). Similarly, we found an upregulation in the mRNA levels of TGF- $\beta 1$ which suggests the usefulness of future more detailed analyses of the role of this cytokine in the development of the senescence phenotype after PUVA treatment. Interestingly, the cellular stress response is not limited to the expression of immediate early genes within 24 hours but the response on mRNA levels occurs for some genes, like SOD2, after 1 week. From this data, it can be concluded that adaptive processes are involved. In fact, especially for genes included in stress response and in cell cycle arrest, we observed that the majority of these genes is up-regulated at early time points after stress, and this up-regulation is maintained for a long time, revealing a characteristic of the adaptive response after the PUVA stress. 
1 PUVA induced premature senescence has been described as an in vitro model for stress-induced

2 premature senescence. Some of the morphological and functional changes in the fibroblast

3 phenotype following exposure to PUVA are described in detail (Ma et al., 2002). This study

4 contributes to the further characterization of the PUVA model.

5 The differences in the transcript levels in both fibroblast strains may reflect the inter-individual

6 variability as well as the fact that AG04431 fibroblasts are derived from fetal skin - known to

7 have different expression patterns compared to juvenile and adult fibroblasts i.e. in wound

8 healing - whereas FF95 fibroblasts were isolated from the foreskin of a one-year-old boy.

9 Additionally, it has been noticed that fibroblasts of different body localization show - at least in

\section{Acknowledgements} part - different gene expression patterns.

In fact, some studies already demonstrated that replicative senescence in fibroblasts can be linked to a state that mimics the early remodeling phase of wound repair (Shelton et al., 1999; Yoon et al., 2004) with an up-regulation of inflammatory and immune responsive genes, and an upregulation of genes involved in cell cycle arrest. Some premature aging disorders have been linked directly to normal aging according to their gene expression profiles (Kyng et al., 2003).

Our data reveal further evidence that the cellular stress response involves the upregulation of genes specifically involved in the DNA-damage response in cellular senescence. Cellular senescence has been established recently as a DNA- and stress-damage response phenomenon (d'Adda di Fagagna et al., 2003; Di Micco et al., 2006; Hovest et al., 2006; von Zglinicki et al., 2005). This observation further substantiates the value of stress-induced cellular senescence models to delineate the underlying cellular and molecular mechanisms of regulation in cellular senescence. For the phototherapeutical treatment of patients with hyperproliferative skin disorders, our investigation will help in future to define adequate treatment schedules in respect to minimize unwanted side effects.

The changes at the mRNA level observed herein after PUVA treatment may better reflect the gene regulatory changes mediated by PUVA treatment during establishment of SIPS than the changes at the protein level. However, it is very often observed that an alteration in mRNA levels does not lead to a similar alteration in the protein abundance (Gygi et al., 1999). Studies at the protein level now could be performed for each of the PUVA-regulated genes identified herein. Such studies would confirm whether the changes observed at the mRNA level translate into changes at the protein expression level.

This work was funded in part by the European Union through the CELLAGE-project (QLK6-CT2001-00616), the individual grants SCHA411/8-2,-3,-4 by the german research foundation DFG to KSK. We acknowledge the Région Wallonne/FSE First-Europe projects "Arrayage" (C. Borlon) and "CosmUV", First-DEI project "Cosmet-X" and First-Spin-Off "Toxico-SIPS". We acknowledge the Région Wallonne "Réseaux II, Senegene" project, "Nanotoxico" project and "Walnut-20". We also thank the European Commission ('Geha' Project, LSHM-CT-2004-503270; 'Link-Age' Project, LSHM-CT-2005-523866, Marie Curie-Transfer of Knowledge 'Matiss' Project, MTKI-CT-2006-042768). O. Toussaint and F. Debacq-Chainiaux are respectively Research Associate and Post-doctoral Researcher of the FNRS, Belgium.

We thank Dr. Joao-Pedro de Magalhaes for critically reading the manuscript. 


\section{References}

Babiychuk, E. B., Babiychuk, V. S., Danilova, V. M., Tregubov, V. S., Sagach, V. F. and Draeger, A., 2002. Stress fibres-a Ca2+ -independent store for annexins? Biochim Biophys Acta 1600, 154-61.

Bates, S., Rowan, S. and Vousden, K. H., 1996. Characterisation of human cyclin G1 and G2: DNA damage inducible genes. Oncogene 13, 1103-9.

Bayreuther, K., Rodemann, H. P., Hommel, R., Dittmann, K., Albiez, M. and Francz, P. I., 1988. Human skin fibroblasts in vitro differentiate along a terminal cell lineage. Proc Natl Acad Sci U S A 85, 5112-6.

Bernerd, F., Del Bino, S. and Asselineau, D., 2001. Regulation of keratin expression by ultraviolet radiation: differential and specific effects of ultraviolet B and ultraviolet a exposure. J Invest Dermatol 117, 1421-9.

Borglum, A. D., Byskov, A., Ragno, P., Roldan, A. L., Tripputi, P., Cassani, G., Dano, K., Blasi, F., Bolund, L. and Kruse, T. A., 1992. Assignment of the urokinase-type plasminogen activator receptor gene (PLAUR) to chromosome 19q13.1-q13.2. Am J Hum Genet 50, 492-7. Budihna, M., Strojan, P., Smid, L., Skrk, J., Vrhovec, I., Zupevc, A., Rudolf, Z., Zargi, M., Krasovec, M., Svetic, B. et al., 1996. Prognostic value of cathepsins B, H, L, D and their endogenous inhibitors stefins A and B in head and neck carcinoma. Biol Chem Hoppe Seyler 377, 385-90.

Campisi, J., Dimri, G. and Hara, E., 1996a. Control of replicative senescence. In Handbook of the biology of aging., (eds E. Schneider and J. Rowe), pp. 121-149. New York: Academic Press. Chainiaux, F., Remacle, J. and Toussaint, O., 2002. Exposure of human skin diploid fibroblasts to repeated subcytotoxic doses of ultraviolet-B induces the overexpression of transforming growth factor-beta1 mRNA. Ann N Y Acad Sci 973, 44-8.

Chen, Q., Fischer, A., Reagan, J. D., Yan, L. J. and Ames, B. N., 1995. Oxidative DNA damage and senescence of human diploid fibroblast cells. Proc Natl Acad Sci U S A 92, 4337-41.

Chen, Q. M., Tu, V. C., Catania, J., Burton, M., Toussaint, O. and Dilley, T., 2000. Involvement of $\mathrm{Rb}$ family proteins, focal adhesion proteins and protein synthesis in senescent morphogenesis induced by hydrogen peroxide. J Cell Sci 113 (Pt 22), 4087-97.

Cox, A. D., Brtva, T. R., Lowe, D. G. and Der, C. J., 1994. R-Ras induces malignant, but not morphologic, transformation of NIH3T3 cells. Oncogene 9, 3281-8.

Cristofalo, V. J. and Pignolo, R. J., 1993. Replicative senescence of human fibroblast-like cells in culture. Physiol Rev 73, 617-38.

d'Adda di Fagagna, F., Reaper, P. M., Clay-Farrace, L., Fiegler, H., Carr, P., Von Zglinicki, T., Saretzki, G., Carter, N. P. and Jackson, S. P., 2003. A DNA damage checkpoint response in telomere-initiated senescence. Nature 426, 194-8.

de Longueville, F., Surry, D., Meneses-Lorente, G., Bertholet, V., Talbot, V., Evrard, S., Chandelier, N., Pike, A., Worboys, P., Rasson, J. P. et al., 2002. Gene expression profiling of drug metabolism and toxicology markers using a low-density DNA microarray. Biochem Pharmacol 64, 137-49.

de Magalhaes, J. P., Chainiaux, F., de Longueville, F., Mainfroid, V., Migeot, V., Marcq, L., Remacle, J., Salmon, M. and Toussaint, O., 2004. Gene expression and regulation in H2O2induced premature senescence of human foreskin fibroblasts expressing or not telomerase. Exp Gerontol 39, 1379-89.

Debacq-Chainiaux, F., Borlon, C., Pascal, T., Royer, V., Eliaers, F., Ninane, N., Carrard, G., Friguet, B., de Longueville, F., Boffe, S. et al., 2005. Repeated exposure of human skin fibroblasts to UVB at subcytotoxic level triggers premature senescence through the TGF-beta1 signaling pathway. J Cell Sci 118, 743-58. 
1 Di Micco, R., Fumagalli, M., Cicalese, A., Piccinin, S., Gasparini, P., Luise, C., Schurra, C.,

2 Garre, M., Nuciforo, P. G., Bensimon, A. et al., 2006. Oncogene-induced senescence is a DNA

3 damage response triggered by DNA hyper-replication. Nature 444, 638-42.

4 Dierick, J. F., Eliaers, F., Remacle, J., Raes, M., Fey, S. J., Larsen, P. M. and Toussaint, O.,

5 2002a. Stress-induced premature senescence and replicative senescence are different phenotypes,

6 proteomic evidence. Biochem Pharmacol 64, 1011-7.

7 Dierick, J. F., Kalume, D. E., Wenders, F., Salmon, M., Dieu, M., Raes, M., Roepstorff, P. and

8 Toussaint, O., 2002b. Identification of 30 protein species involved in replicative senescence and

9 stress-induced premature senescence. FEBS Lett 531, 499-504.

10 Dierick, J. F., Wenders, F., Chainiaux, F., Remacle, J., Fisher, A. B. and Toussaint, O., 2003.

11 Retrovirally mediated overexpression of peroxiredoxin VI increases the survival of WI-38 human

12 diploid fibroblasts exposed to cytotoxic doses of tert-butylhydroperoxide and UVB.

13 Biogerontology 4, 125-31.

14 Dimri, G. P., Lee, X., Basile, G., Acosta, M., Scott, G., Roskelley, C., Medrano, E. E., Linskens, M., Rubelj, I., Pereira-Smith, O. et al., 1995. A biomarker that identifies senescent human cells in culture and in aging skin in vivo. Proc Natl Acad Sci U S A 92, 9363-7.

Dumont, P., Burton, M., Chen, Q. M., Gonos, E. S., Frippiat, C., Mazarati, J. B., Eliaers, F., Remacle, J. and Toussaint, O., 2000. Induction of replicative senescence biomarkers by sublethal oxidative stresses in normal human fibroblast. Free Radic Biol Med 28, 361-73.

Fisher, A. B., Dodia, C., Manevich, Y., Chen, J. W. and Feinstein, S. I., 1999. Phospholipid hydroperoxides are substrates for non-selenium glutathione peroxidase. J Biol Chem 274, 2132634.

Fleischmajer, R., Perlish, J. S., Krieg, T. and Timpl, R., 1981. Variability in collagen and fibronectin synthesis by scleroderma fibroblasts in primary culture. J Invest Dermatol 76, 400-3. Frippiat, C., Chen, Q. M., Zdanov, S., Magalhaes, J. P., Remacle, J. and Toussaint, O., 2001. Subcytotoxic $\mathrm{H} 2 \mathrm{O} 2$ stress triggers a release of transforming growth factor-beta 1, which induces biomarkers of cellular senescence of human diploid fibroblasts. J Biol Chem 276, 2531-7.

Fukami, J., Anno, K., Ueda, K., Takahashi, T. and Ide, T., 1995. Enhanced expression of cyclin D1 in senescent human fibroblasts. Mech Ageing Dev 81, 139-57.

Green, L.M., Reade, J.L., Ware, C.F., 1984. Rapid colorimetric assay for cell viability: application to the quantitation of cytotoxic and growth inhibitory lymphokines. J Immunol Methods. 70,257-68

Gygi, S. P., Rochon, Y., Franza, B. R. and Aebersold, R., 1999. Correlation between protein and mRNA abundance in yeast. Mol Cell Biol 19, 1720-30.

Hayflick, L., 1965. The limited in vitro lifetime of human diploid cell strains. Exp. Cell Res. 37, 614-636.

Herrmann, G., Brenneisen, P., Wlaschek, M., Wenk, J., Faisst, K., Quel, G., Hommel, C., Goerz, G., Ruzicka, T., Krieg, T. et al., 1998. Psoralen photoactivation promotes morphological and functional changes in fibroblasts in vitro reminiscent of cellular senescence. J Cell Sci 111 (Pt 6), 759-67.

Hovest, M. G., Bruggenolte, N., Hosseini, K. S., Krieg, T. and Herrmann, G., 2006. Senescence of human fibroblasts after psoralen photoactivation is mediated by ATR kinase and persistent DNA damage foci at telomeres. Mol Biol Cell 17, 1758-67.

Humphreys, D. T., Carver, J. A., Easterbrook-Smith, S. B. and Wilson, M. R., 1999. Clusterin has chaperone-like activity similar to that of small heat shock proteins. J. Biol. Chem. 274, 68756881.

Jansen, A. P., Dreckschmidt, N. E., Verwiebe, E. G., Wheeler, D. L., Oberley, T. D. and Verma, A. K., 2001. Relation of the induction of epidermal ornithine decarboxylase and hyperplasia to the different skin tumor-promotion susceptibilities of protein kinase $\mathrm{C}$ alpha, -delta and -epsilon transgenic mice. Int J Cancer 93, 635-43.

Jin, R., Bay, B. H., Chow, V. T., Tan, P. H. and Dheen, T., 2001. Significance of metallothionein expression in breast myoepithelial cells. Cell Tissue Res 303, 221-6. 
1 Konopleva, M., Zhao, S., Xie, Z., Segall, H., Younes, A., Claxton, D. F., Estrov, Z., Kornblau, S. 2 M. and Andreeff, M., 1999. Apoptosis. Molecules and mechanisms. Adv Exp Med Biol 457, 217336.

4 Kyng, K. J., May, A., Kolvraa, S. and Bohr, V. A., 2003. Gene expression profiling in Werner 5 syndrome closely resembles that of normal aging. Proc Natl Acad Sci U S A 100, 12259-64.

6 Lee, B. Y., Han, J. A., Im, J. S., Morrone, A., Johung, K., Goodwin, E. C., Kleijer, W. J., galactosidase. Aging Cell 5, 187-95.

Lee, K. S., Lee, W. S., Suh, S. I., Kim, S. P., Lee, S. R., Ryoo, Y. W. and Kim, B. C., 2003. Melatonin reduces ultraviolet-B induced cell damages and polyamine levels in human skin fibroblasts in culture. Exp Mol Med 35, 263-8.

Ma, W., Hommel, C., Brenneisen, P., Peters, T., Smit, N., Sedivy, J., Scharffetter-Kochanek, K. and Wlaschek, M., 2003. Long-term growth arrest of PUVA-treated fibroblasts in G2/M in the absence of p16(INK4a) p21(CIP1) or p53. Exp Dermatol 12, 629-37.

Ma, W., Wlaschek, M., Hommel, C., Schneider, L. A. and Scharffetter-Kochanek, K., 2002. Psoralen plus UVA (PUVA) induced premature senescence as a model for stress-induced premature senescence. Exp Gerontol 37, 1197-201.

Manevich, Y., Sweitzer, T., Pak, J. H., Feinstein, S. I., Muzykantov, V. and Fisher, A. B., 2002. 1-Cys peroxiredoxin overexpression protects cells against phospholipid peroxidation-mediated membrane damage. Proc Natl Acad Sci U S A 99, 11599-604.

Manzow, S., Richter, K. H., Stempka, L., Furstenberger, G. and Marks, F., 2000. Evidence against a role of general protein kinase $\mathrm{C}$ downregulation in skin tumor promotion. Int J Cancer 85, 503-7.

Migliaccio, E., Giorgio, M., Mele, S., Pelicci, G., Reboldi, P., Pandolfi, P. P., Lanfrancone, L. and Pelicci, P. G., 1999. The p66shc adaptor protein controls oxidative stress response and life span in mammals. Nature 402, 309-13.

Mutzhas, M. F., Holzle, E., Hofmann, C. and Plewig, G., 1981. A new apparatus with high radiation energy between 320-460 nm: physical description and dermatological applications. J Invest Dermatol 76, 42-7.

Okamoto, K. and Prives, C., 1999. A role of cyclin G in the process of apoptosis. Oncogene 18, 4606-15.

Park, J. S., Luethy, J. D., Wang, M. G., Fargnoli, J., Fornace, A. J., Jr., McBride, O. W. and Holbrook, N. J., 1992. Isolation, characterization and chromosomal localization of the human GADD153 gene. Gene 116, 259-67.

Pascal, T., Debacq-Chainiaux, F., Chretien, A., Bastin, C., Dabee, A. F., Bertholet, V., Remacle, J. and Toussaint, O., 2005. Comparison of replicative senescence and stress-induced premature senescence combining differential display and low-density DNA arrays. FEBS Lett 579, 3651-9. Patil, C. K., Mian, I. S. and Campisi, J., 2005. The thorny path linking cellular senescence to organismal aging. Mech Ageing Dev 126, 1040-5.

Poss, K. D. and Tonegawa, S., 1997. Reduced stress defense in heme oxygenase 1-deficient cells. Proc Natl Acad Sci U S A 94, 10925-30.

Ressler, S., Bartkova, J., Niederegger, H., Bartek, J., Scharffetter-Kochanek, K., Jansen-Durr, P. and Wlaschek, M., 2006. p16INK4A is a robust in vivo biomarker of cellular aging in human skin. Aging Cell 5, 379-89.

Rittie, L. and Fisher, G. J., 2002. UV-light-induced signal cascades and skin aging. Ageing Res Rev 1, 705-20. Salmon, M., Dedessus Le Moutier, J., Wenders, F., Chiarizia, S., Eliaers, F., Remacle, J., Royer, V., Pascal, T. and Toussaint, O., 2004. Role of the PLA2-independent peroxiredoxin VI activity in the survival of immortalized fibroblasts exposed to cytotoxic oxidative stress. FEBS Lett 557, 26-32. 
1 Sator, P. G., Schmidt, J. B. and Honigsmann, H., 2002. Objective assessment of photoageing

2 effects using high-frequency ultrasound in PUVA-treated psoriasis patients. Br J Dermatol 147, 3 291-8.

4 Shelton, D. N., Chang, E., Whittier, P. S., Choi, D. and Funk, W. D., 1999. Microarray analysis 5 of replicative senescence. Curr Biol 9, 939-45.

6 Sherr, C. J. and Roberts, J. M., 1999. CDK inhibitors: positive and negative regulators of G17 phase progression. Genes Dev 13, 1501-12.

8 Simpkins, C. O., 2000. Metallothionein in human disease. Cell Mol Biol (Noisy-le-grand) 46, 9 465-88.

10 Strange, R. C., Lear, J. T. and Fryer, A. A., 1998. Polymorphism in glutathione S-transferase loci 11 as a risk factor for common cancers. Arch Toxicol Suppl 20, 419-28.

12 von Zglinicki, T., Saretzki, G., Ladhoff, J., d'Adda di Fagagna, F. and Jackson, S. P., 2005.

13 Human cell senescence as a DNA damage response. Mech Ageing Dev 126, 111-7.

14 Waghray, A., Keppler, D., Sloane, B. F., Schuger, L. and Chen, Y. Q., 2002. Analysis of a truncated form of cathepsin $\mathrm{H}$ in human prostate tumor cells. J Biol Chem 277, 11533-8. Wlaschek, M., Hommel, C., Wenk, J., Brenneisen, P., Ma, W., Herrmann, G. and ScharffetterKochanek, K., 2000a. Isolation and identification of psoralen plus ultraviolet A (PUVA)-induced genes in human dermal fibroblasts by polymerase chain reaction-based subtractive hybridization. J Invest Dermatol 115, 909-13.

Wlaschek, M., Ma, W., Jansen-Durr, P. and Scharffetter-Kochanek, K., 2003. Photoaging as a consequence of natural and therapeutic ultraviolet irradiation--studies on PUVA-induced senescence-like growth arrest of human dermal fibroblasts. Exp Gerontol 38, 1265-70.

Wlaschek, M., Wenk, J., Brenneisen, P., Hommel, C., Ma, W., Herrmann, G. and ScharffetterKochanek, K., 2000b. PCR-based subtractive hybridization identifies repressed genes in growtharrested human dermal fibroblasts following combined treatment with 8-methoxypsoralen and UVA irradiation (PUVA). Exp Gerontol 35, 573-81.

$\mathrm{Xu}$, J. and Morris, G. F., 1999. p53-mediated regulation of proliferating cell nuclear antigen expression in cells exposed to ionizing radiation. Mol Cell Biol 19, 12-20.

Yoon, I. K., Kim, H. K., Kim, Y. K., Song, I. H., Kim, W., Kim, S., Baek, S. H., Kim, J. H. and Kim, J. R., 2004. Exploration of replicative senescence-associated genes in human dermal fibroblasts by cDNA microarray technology. Exp Gerontol 39, 1369-78.

Zdanov, S., Debacq-Chainiaux, F., Remacle, J. and Toussaint, O., 2006. Identification of p38MAPK-dependent genes with changed transcript abundance in H2O2-induced premature senescence of IMR-90 hTERT human fibroblasts. FEBS Letters 580, 6455-6463. 

3 4 5 6
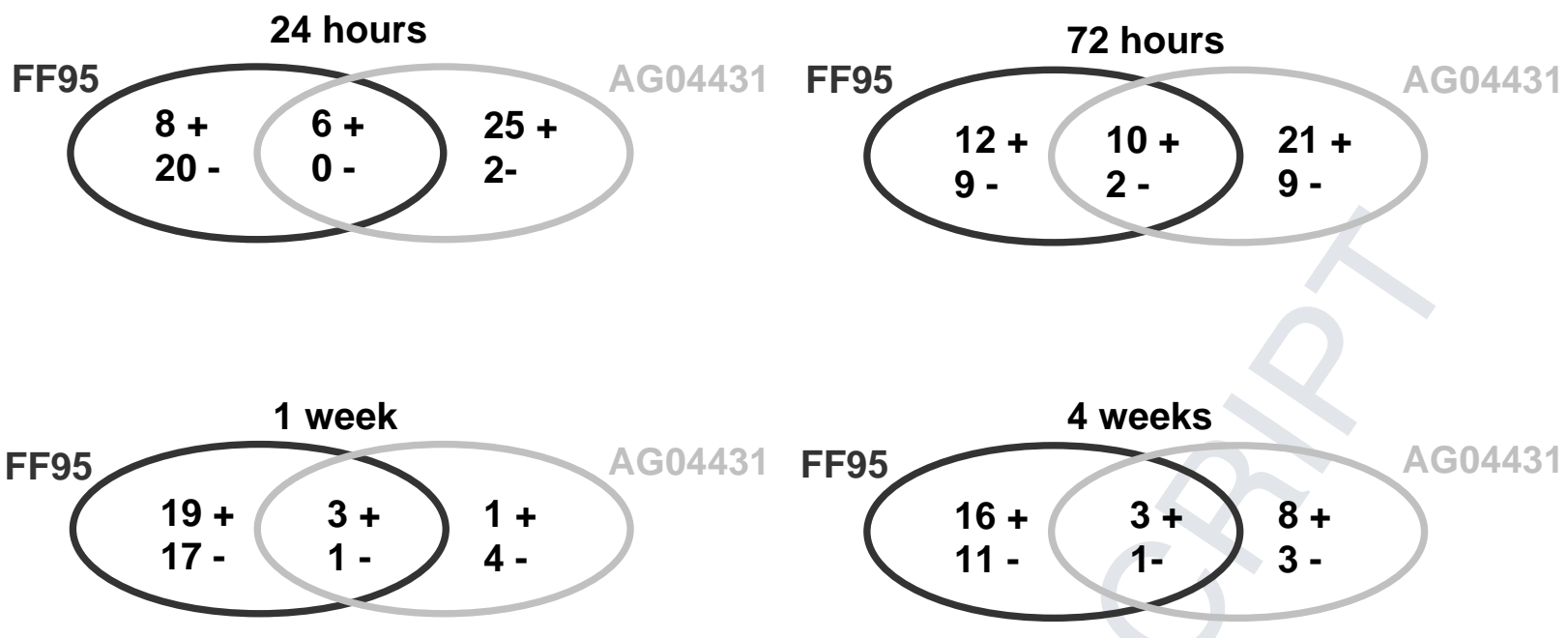

Figure 1: Sorting of the numbers of genes with differential expression after PUVA treatment (increased (+) or decreased (-) transcript abundance). Total RNA was collected at $24 \mathrm{~h}, 72 \mathrm{~h}, 1$ week and 4 weeks after PUVA treatment.

\begin{tabular}{|c|c|c|}
\hline Genes & Positions (bp) & Sequences \\
\hline \multirow[t]{2}{*}{$\mathrm{p} 21^{\mathrm{WAF-1}}$} & $495-515$ & $\overline{5}^{\prime}$ - CTG GAG ACT CTC AGG GTC GAA - 3' \\
\hline & $599-617$ & 5' - CCA GGA CTG CAG GCT TCC T - 3' \\
\hline \multirow[t]{2}{*}{ HMOX } & $799-820$ & 5' - CCA GCA ACA AAG TGC AAG ATT C - 3' \\
\hline & 925-946 & 5' - CAC ATG GCA TAA AGC CCT ACA G - 3' \\
\hline \multirow[t]{2}{*}{ CTGF } & $242-258$ & 5' - CAA GCT GCC CGG GAA AT-3' \\
\hline & $365-384$ & 5' - GGA CCA GGC AGT TGG CTC TA -3' \\
\hline \multirow[t]{2}{*}{ MT2A } & 134-154 & 5' - GCA CTT CGT GCA AGA AAA GCT - 3, \\
\hline & $184-201$ & 5' - GCA GCC TTG GGC ACA CTT - 3' \\
\hline \multirow[t]{2}{*}{ SOD2 } & $632-653$ & 5' - CAA ATT GCT GCT TGT CCA AAT C - 3' \\
\hline & $607-716$ & 5' - CGT GCT CCC ACA CAT CAA TC - 3' \\
\hline GAPDH & $\begin{array}{l}942-963 \\
1033-1053\end{array}$ & $\begin{array}{l}5,- \text { ACC CAC TCC TCC ACC TTT GAC - 3, } \\
\text { 5' - GTC CAC CAC CCT GTT GTC GTA - 3, }\end{array}$ \\
\hline
\end{tabular}

Table 1: Primers used for quantitative Real Time RT-PCR 
1 Table 2 (A) Genes overexpressed (control=1.00)

\begin{tabular}{|c|c|c|c|c|c|c|}
\hline 7. Name & Genbank & Gene & $24 \mathrm{~h}$ & $72 \mathrm{~h}$ & 1 Week & 4 Weeks \\
\hline \multicolumn{7}{|l|}{ 8. Apoptosis / Inflammation } \\
\hline BCLX & NM_001191 & BCLX & 2.14 & 2.40 & 1.97 & 2.42 \\
\hline \multicolumn{7}{|l|}{ Cell adhesion / Circulation } \\
\hline Thrombospondin & X14787 & THBS1 & & & 2.53 & 2.02 \\
\hline Plasminogen activator inhibitor type 1 & M14083 & PAI1 & & & & 1.79 \\
\hline Plasminogen activator inhibitor type 2 & $\mathrm{~J} 02685$ & $\mathrm{PAI} 2$ & & 2.42 & & \\
\hline \multicolumn{7}{|l|}{ Cell cycle } \\
\hline Cyclin D1 & NM_053056 & CCND1 & & 2.06 & & 2.73 \\
\hline Cyclin dependent kinase inhibitor $1 \mathrm{~A}$ & U03106 & & 9.77 & 4.26 & 5.03 & 2.78 \\
\hline Cyclin G & U53328 & CCNG & & & 2.00 & \\
\hline Proliferating cell nuclear antigen & NM_002592 & PCNA & 1.84 & 2.15 & & \\
\hline \multicolumn{7}{|l|}{ Cell differentiation } \\
\hline Keratin17 & X62571 & KRT17 & 5.32 & & & \\
\hline Keratin19 & NM_002276 & KRT19 & & 2.32 & & \\
\hline Inhibitor of DNA binding 1 & $\mathrm{X} 77956$ & ID1 & 2.63 & & & \\
\hline \multicolumn{7}{|l|}{ Cell signalling / receptor } \\
\hline Nuclear receptor subfamily 1 & NM_021724 & EAR1 & 3.39 & & & \\
\hline Urokinase receptor & NM_002659 & PLAUR & & 1.71 & & \\
\hline Early growth response 1 & NM_001964 & EGR1 & 1.62 & 2.54 & & \\
\hline \multicolumn{7}{|l|}{ Chromosomal processing } \\
\hline Histone $2 \mathrm{~b}$ member $\mathrm{B} / \mathrm{S}$ consensus & NM_080593 & $\mathrm{H} 2 \mathrm{~B} / \mathrm{S}$ & 1.60 & & & 4.43 \\
\hline \multicolumn{7}{|l|}{ Extracellular matrix / Cell structure } \\
\hline Matrix metalloproteinase 2 & NM_004530 & MMP2 & & & 2.07 & 1.73 \\
\hline Matrix metalloproteinase 3 & NM_002422 & MMP3 & & 1.72 & 2.17 & 2.42 \\
\hline Matrix metalloproteinase 7 & NM_002423 & MMP7 & & & 2.76 & \\
\hline Matrix metalloproteinase 10 & NM_002425 & MMP10 & & & 3.39 & \\
\hline Matrix metalloproteinase 14 & NM_004995 & MMP14 & & & & 2.97 \\
\hline Tissue inhibitor of metalloproteinase 2 & NM_003255 & TIMP2 & & & 1.67 & \\
\hline Osteonectin & NM_003118 & Oste & & & 1.86 & 2.30 \\
\hline Fibronectin & $\mathrm{X} 02761$ & FN1 & & 2.02 & & \\
\hline Collagen III-alpha1 & NM_000090 & COL3A1 & & & 2.16 & \\
\hline Metalloprotease 1 & $\mathrm{AF} 061243$ & MP1 & & 1.92 & & \\
\hline Transgelin & M95787 & SM22 & & 2.98 & & \\
\hline \multicolumn{7}{|l|}{ Growth factors and cytokines } \\
\hline Insulin growth factor binding protein 2 & M35410 & IGFBP2 & & & & 1.89 \\
\hline Insulin growth factor binding protein 5 & M65062 & IGFBP5 & & & 3.12 & 6.59 \\
\hline Connective tissue growth factor & U14750 & CTGF & & 1.81 & & 4.35 \\
\hline Protease serine 1 & NM_002775 & PRSS11 & 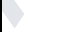 & & 1.88 & \\
\hline Interleukin $1 \beta$ & M15330 & IL1B & & 1.78 & & \\
\hline Transforming Growth Factor $\beta 1$ & NM_000660 & TGFB1 & 2.02 & & & \\
\hline Bone morphogenic protein 2 & NM_001200 & BMP2 & 2.92 & & & \\
\hline \multicolumn{7}{|l|}{ Intermediate / Protein metabolism } \\
\hline B1 galactosidase & M34423 & GLB1 & & & 1.79 & 2.05 \\
\hline Creatin kinase brain & M16364 & CKB & & 1.53 & & 2.05 \\
\hline Ornithin decarboxylase 1 & NM_002539 & ODC & & 3.21 & & \\
\hline Cathepsin D & M11233 & CTSD & & & 1.98 & 2.10 \\
\hline Cathepsin $\mathrm{H}$ & NM_004390 & CTSH & & & & 5.92 \\
\hline \multicolumn{7}{|l|}{ Oncogenesis } \\
\hline SHC transforming protein 1 & U73377 & SHC & & & 1.98 & \\
\hline R-ras & NM_006270 & RRAS & & & 2.52 & \\
\hline \multicolumn{7}{|l|}{ Stress response } \\
\hline Heme oxygenase & NM_002133 & HMOX & 2.88 & 2.60 & & 2.13 \\
\hline Anti oxidant protein 2 & NM_004905 & AOP2 & & 1.59 & 1.87 & \\
\hline Heat shock $90 \mathrm{kD}$ protein 1 alpha & $\mathrm{X} 15183$ & HSP90-alpha & & 2.07 & & \\
\hline DNA damage inducible transcript 3 & S40706 & GADD153 & 4.32 & 2.35 & & \\
\hline Superoxide dismutase & NM_000636 & SOD2 & & & 17.74 & 1.96 \\
\hline Glutathione peroxidase & M21304 & GPX & 2.33 & 1.80 & 1.75 & \\
\hline Gluthatione S-transferase theta 1 & NM_000853 & GSTT1 & & & 1.57 & \\
\hline Annexin 1 & NM_000700 & ANX1 & & 2.69 & & \\
\hline
\end{tabular}


2 Table 2 (B) Genes down-regulated (control=1.00)

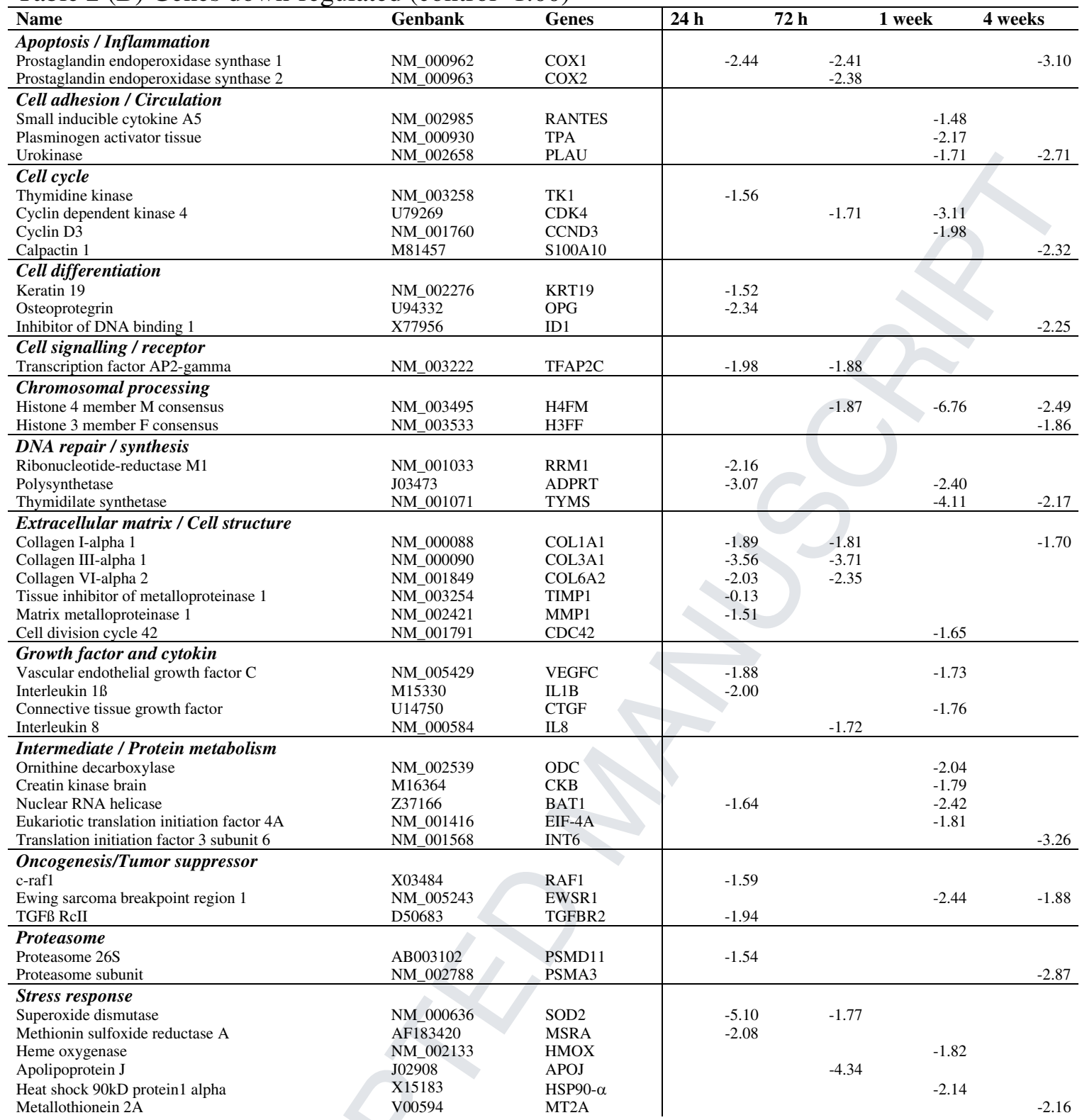

3 Table 2 (A) and (B): List of genes with increased (A) and decreased (B) transcript level in FF95 4 human skin fibroblasts after PUVA treatment (Column $1=$ gene names grouped by function, 5 column $2=$ GenBank accession number). Total RNA was collected at $24 \mathrm{~h}, 72 \mathrm{~h}, 1$ week and 4 6 weeks after PUVA treatment. Empty boxes = level unchanged. 
$1 \quad$ Table 3 (A) Genes overexpressed (control=1.00)

\begin{tabular}{|c|c|c|c|c|c|c|}
\hline Name & Genbank & Genes & $24 \mathrm{~h}$ & $72 \mathrm{~h}$ & 1 week & 4 weeks \\
\hline $\begin{array}{l}\text { Apoptosis / Inflammation } \\
\text { Bcl2 associated X protein } \\
\text { BCLX }\end{array}$ & $\begin{array}{l}\text { NM_004324 } \\
\text { NM_001191 }\end{array}$ & $\begin{array}{l}\text { BAX } \\
\text { BCLX }\end{array}$ & $\begin{array}{l}1.65 \\
2.24\end{array}$ & 1.53 & & \\
\hline $\begin{array}{l}\text { Cell cycle } \\
\text { Cyclin G } \\
\text { Cyclin dependent kinase inhibitor 2A } \\
\text { Cyclin dependent kinase inhibitor 1A } \\
\text { Cyclin D1 } \\
\text { Proliferating cell nuclear antigen } \\
\text { Cyclin D3 }\end{array}$ & $\begin{array}{l}\text { U53328 } \\
\text { L27211 } \\
\text { U03106 } \\
\text { NM_053056 } \\
\text { NM_002592 } \\
\text { NM_001760 } \\
\end{array}$ & $\begin{array}{l}\text { CCNG } \\
\text { p16 } \\
\text { p21 } \\
\text { CCND1 } \\
\text { PCNA } \\
\text { CCND3 } \\
\end{array}$ & $\begin{array}{l}2.02 \\
3.36 \\
\\
3.63 \\
1.63 \\
\end{array}$ & $\begin{array}{l}2.17 \\
3.57 \\
2.77 \\
4.36\end{array}$ & 2.60 & $\begin{array}{l}2.07 \\
2.71 \\
3.30\end{array}$ \\
\hline $\begin{array}{l}\text { Cell differentiation } \\
\text { Keratin } 19 \\
\text { Sorcin }\end{array}$ & $\begin{array}{l}\text { NM_002276 } \\
\text { NM_003130 }\end{array}$ & $\begin{array}{l}\text { KRT19 } \\
\text { SRI }\end{array}$ & 1.79 & 1.81 & & \\
\hline $\begin{array}{l}\text { Cell signaling receptor } \\
\text { Urokinase receptor }\end{array}$ & NM_002659 & PLAUR & 1.63 & & & \\
\hline $\begin{array}{l}\text { Chromosomal processing } \\
\text { Histone } 2 \mathrm{~b} \text { member } \mathrm{B} / \mathrm{S} \text { consensus }\end{array}$ & NM_080593 & $\mathrm{H} 2 \mathrm{~B} / \mathrm{S}$ & 2.00 & 4.22 & & 2.37 \\
\hline $\begin{array}{l}\text { Circulation } \\
\text { Plasminogen activator tissue }\end{array}$ & NM_000930 & TPA & 1.72 & 2.15 & & \\
\hline $\begin{array}{l}\text { DNA repair / synthesis } \\
\text { Thymidylate synthetase }\end{array}$ & NM_001071 & TYMS & 1.93 & & & \\
\hline $\begin{array}{l}\text { Extracellular matrix / Cell structure } \\
\text { Matrix metalloproteinase } 1 \\
\text { Matrix metalloproteinase } 14 \\
\text { Cell division cycle } 42 \\
\end{array}$ & $\begin{array}{l}\text { NM_002421 } \\
\text { NM_004995 } \\
\text { NM_001791 }\end{array}$ & $\begin{array}{l}\text { MMP1 } \\
\text { MMP14 } \\
\text { CDC42 }\end{array}$ & $\begin{array}{l}5.03 \\
1.89 \\
1.75\end{array}$ & $\begin{array}{l}3.96 \\
2.25 \\
2.13\end{array}$ & 1.72 & \\
\hline $\begin{array}{l}\text { Growth factor and cytokin } \\
\text { TGF } \beta 1\end{array}$ & NM_000660 & TGFB1 & 1.55 & & & \\
\hline $\begin{array}{l}\text { Intermediate / Protein metabolism } \\
\text { Electron transfer flavoprotein beta } \\
\text { Pyruvate kinase muscle } \\
\text { Ornithin decarboxylase } 1 \\
81 \text { galactosidase } \\
\text { Translation initiation factor } 3 \text { subunit } 6 \\
60 \text { S-ribosomal protein L3 } \\
\text { Eukaryotic translation initiation factor 4A } \\
\text { Nuclear RNA helicase } \\
\text { Eukaryotic translation elongation factor A1 } \\
\text { Calnexin } \\
\text { Cathepsin H }\end{array}$ & $\begin{array}{l}\text { NM_001985 } \\
\text { M26252 } \\
\text { NM_002539 } \\
\text { M34423 } \\
\text { NM_001568 } \\
\text { NM_000967 } \\
\text { NM_001416 } \\
\text { Z37166 } \\
\text { AY043301 } \\
\text { NM_001746 } \\
\text { NM_004390 }\end{array}$ & $\begin{array}{l}\text { ETFB } \\
\text { PKM2 } \\
\text { ODC } \\
\text { GLB1 } \\
\text { INT6 } \\
\text { RPL3 } \\
\text { EIF-4A } \\
\text { BAT1 } \\
\text { EF1A } \\
\text { CANX } \\
\text { CTSH }\end{array}$ & $\begin{array}{l}2.43 \\
1.54 \\
1.99 \\
\\
1.86 \\
1.61 \\
\\
1.41 \\
1.61\end{array}$ & $\begin{array}{l}1.70 \\
1.83 \\
\\
1.77 \\
1.58 \\
1.61 \\
1.74 \\
3.03 \\
1.68\end{array}$ & & 1.76 \\
\hline $\begin{array}{l}\text { Oncogenesis } \\
\text { SHC transforming protein } 1 \\
\text { R-ras } \\
\text { Calgizzarin } \\
\text { Ewing sarcoma breakpoint region } 1 \\
\end{array}$ & $\begin{array}{l}\text { U73377 } \\
\text { NM_006270 } \\
\text { D38583 } \\
\text { NM_005243 }\end{array}$ & $\begin{array}{l}\text { SHC } \\
\text { RRAS } \\
\text { S100A11 } \\
\text { EWSR1 }\end{array}$ & 1.67 & $\begin{array}{l}1.71 \\
1.75\end{array}$ & & $\begin{array}{l}1.68 \\
2.12\end{array}$ \\
\hline $\begin{array}{l}\text { Proteasome } \\
\text { Proteasome (prosome, macropain) } 36 \mathrm{~S} \text { subunit } \\
\text { Proteasome (prosome, macropain) subunit } 2 \\
\text { Proteasome (prosome, macropain) subunit } 3 \\
\text { Proteasome 26S }\end{array}$ & $\begin{array}{l}\text { NM_002807 } \\
\text { NM_002787 } \\
\text { NM_002788 } \\
\text { AB003102 }\end{array}$ & $\begin{array}{l}\text { PSMD1 } \\
\text { PSMA2 } \\
\text { PSMA3 } \\
\text { PSMD11 } \\
\end{array}$ & $\begin{array}{l}2.01 \\
1.84\end{array}$ & $\begin{array}{l}2.76 \\
2.15 \\
1.99\end{array}$ & & \\
\hline $\begin{array}{l}\text { Stress response } \\
\text { Heme oxygenase } \\
\text { Anti oxidant protein } 2 \\
\text { Metallothionein } 2 \mathrm{~A} \\
\text { Heat shock } 90 \mathrm{kD} \text { protein } 1 \text { alpha } \\
\text { Heat shock } 70 \mathrm{kD} \text { protein } 1 \\
\text { Heat shock } 40 \mathrm{kD} \text { protein } 1 \\
\text { Annexin } 1 \\
\text { Gluthatione } S \text { transferase theta } 1 \\
\text { Glutathione peroxidase } \\
\text { Superoxide dismutase } \\
\text { DNA damage inducible transcript } 3\end{array}$ & $\begin{array}{l}\text { NM_002133 } \\
\text { NM_004905 } \\
\text { V00594 } \\
\text { X15183 } \\
\text { AB023420 } \\
\text { D49547 } \\
\text { NM_000700 } \\
\text { NM_000853 } \\
\text { M21304 } \\
\text { NM_000636 } \\
\text { S40706 }\end{array}$ & $\begin{array}{l}\text { HMOX } \\
\text { AOP2 } \\
\text { MT2A } \\
\text { HSP90- } \alpha \\
\text { HSP70 } \\
\text { HSP40 } \\
\text { ANX1 } \\
\text { GSTT1 } \\
\text { GPX } \\
\text { SOD2 } \\
\text { GADD153 }\end{array}$ & $\begin{array}{l}1.77 \\
1.83 \\
1.54 \\
1.89\end{array}$ & $\begin{array}{l}1.62 \\
1.96 \\
3.64\end{array}$ & $\begin{array}{l}2.31 \\
3.83\end{array}$ & $\begin{array}{l}1.99 \\
2.78 \\
6.17 \\
2.27\end{array}$ \\
\hline
\end{tabular}


$1 \quad$ (B) Genes down-regulated (control=1.00)

\begin{tabular}{|c|c|c|c|c|c|c|}
\hline Name & Genbank & Genes & $24 \mathrm{~h}$ & $72 \mathrm{~h}$ & 1 week & 4 weeks \\
\hline $\begin{array}{l}\text { Cell signaling/receptor } \\
\text { Interleukin1 receptor-alpha }\end{array}$ & U32324 & IL11RA & & -1.47 & & \\
\hline $\begin{array}{l}\text { Chromosomal processing } \\
\text { Histone } 4 \text { member M consensus }\end{array}$ & NM_003495 & $\mathrm{H} 4 \mathrm{FM}$ & -2.12 & & & \\
\hline $\begin{array}{l}\text { Cell adhesion / Circulation } \\
\text { Plasminogen activator inhibitor type } 1\end{array}$ & M14083 & PAI1 & & -1.47 & & -3.42 \\
\hline $\begin{array}{l}\text { Extracellular matrix / Cell structure } \\
\text { Matrix metalloproteinase } 1 \\
\text { Collagen I alpha } 1 \\
\text { Collagen III alpha } 1 \\
\text { Osteonectin } \\
\text { Fibronectin } \\
\text { Transgelin } \\
\end{array}$ & $\begin{array}{l}\text { NM_002421 } \\
\text { NM_000088 } \\
\text { NM_000090 } \\
\text { NM_003118 } \\
\text { X02761 } \\
\text { M95787 }\end{array}$ & $\begin{array}{l}\text { MMP1 } \\
\text { COL1A1 } \\
\text { COL3A1 } \\
\text { Oste } \\
\text { FN1 } \\
\text { SM22 } \\
\end{array}$ & & $\begin{array}{l}-2.23 \\
-2.31 \\
-1.59 \\
-1.73 \\
-2.04 \\
\end{array}$ & $\begin{array}{l}-2.22 \\
-2.10 \\
-1.89 \\
\end{array}$ & -6.29 \\
\hline $\begin{array}{l}\text { Growth factor and cytokin } \\
\text { Insulin growth factor binding protein } 3 \\
\text { Insulin growth factor binding protein } 5 \\
\text { Connective tissue growth factor }\end{array}$ & $\begin{array}{l}\text { X64875 } \\
\text { M65062 } \\
\text { U14750 }\end{array}$ & $\begin{array}{l}\text { IGFBP3 } \\
\text { IGFBP5 } \\
\text { CTGF }\end{array}$ & -1.83 & $\begin{array}{l}-2.16 \\
-1.22 \\
-2.26\end{array}$ & $\begin{array}{l}-2.78 \\
-2.50\end{array}$ & -2.27 \\
\hline $\begin{array}{l}\text { Stress response } \\
\text { Metallothionein } 2 \mathrm{~A} \\
\text { Heat shock } 27 \mathrm{kD} \text { protein } 1\end{array}$ & $\begin{array}{l}\text { V00594 } \\
\text { AB020027 }\end{array}$ & $\begin{array}{l}\text { MT2A } \\
\text { HSP27 }\end{array}$ & & -1.60 & & -4.51 \\
\hline
\end{tabular}

2 Table 3 (A) and (B): List of genes with increased (A) and decreased (B) transcript level in 3 AG04431 human skin fibroblasts after PUVA treatment (Column 1 = gene names grouped by 4 function, column 2 = GenBank accession number). Total RNA was collected at $24 \mathrm{~h}, 72 \mathrm{~h}, 1$ 5 week and 4 weeks after PUVA treatment. Empty boxes = level unchanged. 
1 Table 4 (A) Genes overexpressed (control=1.00)

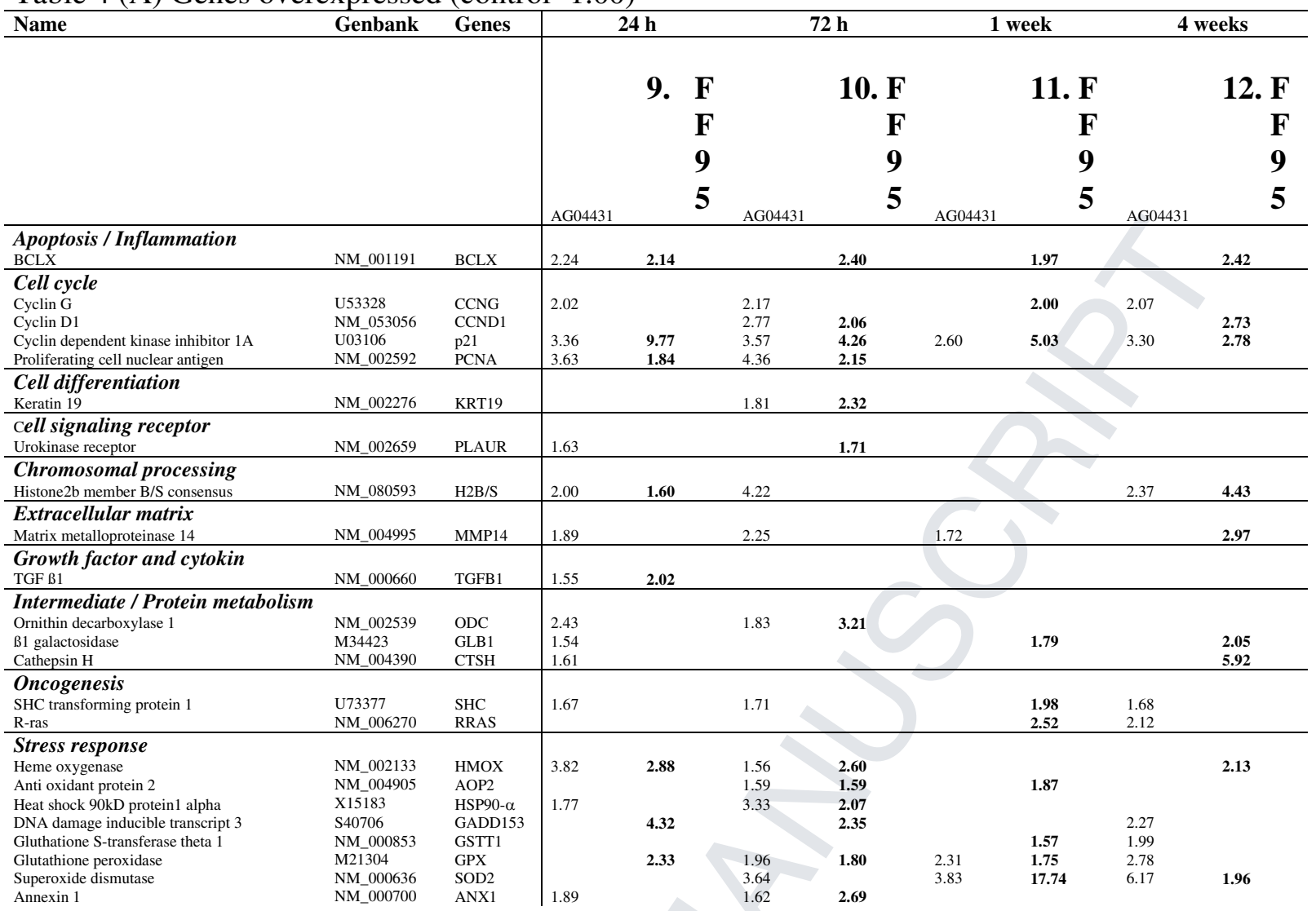

3 Table 4 (B) Genes down-regulated (control=1.00)

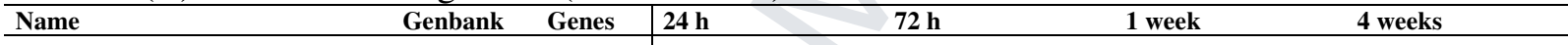

\begin{tabular}{|c|c|c|c|c|c|c|c|c|c|c|}
\hline & & & AG04431 & 13 & 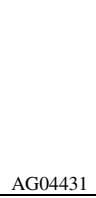 & $\begin{array}{r}\text { 14. F } \\
F \\
9 \\
5\end{array}$ & AG04431 & FF95 & AG04431 & FF95 \\
\hline $\begin{array}{l}\text { Chromosomal processing } \\
\text { Histone } 4 \text { member M consensus }\end{array}$ & NM_003495 & $\mathrm{H} 4 \mathrm{FM}$ & $y$ & -2.12 & -1.87 & & -6.76 & & -2.49 & \\
\hline $\begin{array}{l}\text { Extracellular matrix } \\
\text { Collagen I-alph } 1 \\
\text { Collagen III-alpha } 1 \\
\text { Matrix metalloproteinase } 1\end{array}$ & $\begin{array}{l}\text { NM_000088 } \\
\text { NM_000090 } \\
\text { NM_002421 }\end{array}$ & $\begin{array}{l}\text { COL1A1 } \\
\text { COL3A1 } \\
\text { MMP1 }\end{array}$ & $\begin{array}{l}-1.89 \\
-3.56 \\
-1.51\end{array}$ & & $\begin{array}{l}-1.81 \\
-3.71\end{array}$ & $\begin{array}{l}-2.23 \\
-2.31\end{array}$ & & -2.22 & -1.70 & -6.29 \\
\hline $\begin{array}{l}\text { Growth factor and cytokin } \\
\text { Connective tissue growth factor }\end{array}$ & U14750 & $\mathrm{CTGF}$ & & & & -2.26 & -1.76 & -2.50 & & \\
\hline $\begin{array}{l}\text { Stress response } \\
\text { Metallothionein } 2 \mathrm{~A}\end{array}$ & v00594 & MT2A & & & & & & & -2.16 & -4.51 \\
\hline
\end{tabular}

Table 4 (A) and (B): List of genes with increased (A) and decreased (B) transcript level in both strains of fibroblasts (AG04431-FF95) (Column 1 = gene names grouped by function, column 2 $=$ GenBank accession number). Total RNA collected $24 \mathrm{~h}, 72 \mathrm{~h}, 1$ week and 4 weeks after PUVA treatment. Empty boxes = level unchanged. 
1

\begin{tabular}{lccccc} 
& \multicolumn{2}{l}{ FF95 } & & & AG04431 \\
\cline { 2 - 3 } p21 $^{\text {WAF-1 }}$ & Real Time RT-PCR & cDNA Array & & Real Time RT-PCR & cDNA Array \\
\hline 24 hours & 32.2 & 9.8 & 6.5 & 3.4 \\
72 hours & 13.7 & 4.3 & & 18.8 & 3.6 \\
1week & 10.2 & 5.0 & & 6.0 & 2.6 \\
4 weeks & 8.3 & 2.8 & & 3.5 & 3.3
\end{tabular}

2

\begin{tabular}{|c|c|c|c|c|c|}
\hline \multirow[b]{2}{*}{2.5.} & \multicolumn{3}{|c|}{ FF95 } & \multicolumn{2}{|l|}{ AG04431 } \\
\hline & $H M O X$ & Real Time RT-PCR & cDNA Array & Real Time RT-PCR & cDNA Array \\
\hline $24 \mathrm{hou}$ & & 4.9 & 2.9 & 2.1 & 3.8 \\
\hline 72 hou & & 2.4 & 2.6 & 1.9 & 1.6 \\
\hline 1 week & & -2.0 & -1.8 (N.S.) & -1.2 (N.S.) & 1.3 (N.S.) \\
\hline 4 weel & & 2.5 & 2.1 & 1.1 (N.S.) & -1.1 (N.S.) \\
\hline
\end{tabular}

3

\begin{tabular}{|c|c|c|c|c|}
\hline \multirow[b]{2}{*}{ CTGF } & \multicolumn{2}{|l|}{ FF95 } & \multicolumn{2}{|l|}{ AG04431 } \\
\hline & Real Time RT-PCR & cDNA Array & Real Time RT-PCR & cDNA Array \\
\hline 24 hours & 1.1 (N.S.) & -1.3 (N.S.) & -2.9 & -1.5 (N.S.) \\
\hline 72 hours & 1.4 & 1.8 (N.S.) & -1.3 & -2.2 \\
\hline 1week & -1.4 & -1.7 & -3.3 & -2.5 \\
\hline 4 weeks & 1.2 (N.S.) & 4.4 (N.S.) & 1.2 (N.S.) & -1.8 (N.S.) \\
\hline
\end{tabular}

4

\begin{tabular}{lcccccc} 
& \multicolumn{2}{l}{ FF95 } & & & AG04431 & \\
\cline { 2 - 3 } \cline { 5 - 6 } MT2A & Real Time RT-PCR & cDNA Array & & Real Time RT-PCR & cDNA Array \\
\hline 24 hours & -4.1 & -1.2 (N.S.) & & -1.3 & -1.8 (N.S.) \\
72 hours & -1.5 & -1.5 (N.S.) & & 5.7 & 2.0 \\
1week & -3.4 & -1.5 (N.S.) & & -1.8 & -1.4 (N.S.) \\
4 weeks & -4.4 & -2.2 & & -1.5 & -4.5
\end{tabular}

5

\begin{tabular}{lccccc} 
& \multicolumn{2}{l}{ FF95 } & & & \multicolumn{2}{c}{ AG04431 } \\
\cline { 2 - 3 } SOD2 & Real Time RT-PCR & cDNA Array & & Real Time RT-PCR & cDNA Array \\
\hline 24 hours & -8.2 & -4.8 (N.S.) & & -2.0 & -1.1 (N.S.) \\
72 hours & -2.0 & -1.8 (N.S.) & 17.7 & 3.5 & 3.5 \\
1week & 23.4 & 2.0 & 4.1 & 3.8 \\
4 weeks & 3.3 & & 7.5 & 6.2
\end{tabular}

6

10

11

12

Table 5 : Comparison between the data obtained with real-time RT-PCR and the DualChip human aging for FF95 fibroblasts and AG04431 fibroblasts for 5 genes at 24 h, 72 h, 1 week and 4 weeks after PUVA treatment (N.S.: non significant), cut off : 1,3. 